Egyptian Journal of Aquatic Biology \& Fisheries

Zoology Department, Faculty of Science,

Ain Shams University, Cairo, Egypt.

ISSN $1110-6131$

Vol. 24(3): 257 - 270 (2020)

www.ejabf.journals.ekb.eg

\title{
Seasonal variations of heavy metals in the marine bivalve Cerastoderma glaucum (Bruguière, 1789) from Temsah Lake, Ismailia, Egypt, and their relation to antioxidant enzymes
}

\author{
Salwa A. El-Saidy ${ }^{1, *}$, Gihan M. El-Khodary ${ }^{1}$, Nahla E. Omran ${ }^{2}$, Karolin K. Abd El-Aziz ${ }^{1}$ \\ and Mohamed H. Mona ${ }^{2}$
}

1- Department of Zoology, Faculty of Science, Damanhour University, Egypt.

2- Department of Zoology, Faculty of Science, Tanta University, Egypt.

*Corresponding Author: salwa_elseedy@yahoo.com

\section{ARTICLE INFO}

Article History:

Received: March 8, 2020

Accepted: April 27, 2020

Online: May 2020

Keywords:

Cerastoderma glaucum

Temsah Lake

Heavy metals

Lipid peroxidation

Antioxidant enzymes

\section{ABSTRACT}

Cerastoderma glaucum is a common bivalve in Temsah Lake. It plays important direct and/or indirect roles in the nutrient cycle. This work determined the seasonal variation of heavy metals [copper $(\mathrm{Cu})$, iron $(\mathrm{Fe})$, magnesium $(\mathrm{Mg})$, manganese $(\mathrm{Mn})$, zinc $(\mathrm{Zn})$, chromium $(\mathrm{Cr})$, nickel $(\mathrm{Ni})$, cobalt $(\mathrm{Co})$, cadmium $(\mathrm{Cd})$ and lead $(\mathrm{Pb})]$ in the tissue of the investigated bivalve, and the effect of these metals on the antioxidant enzymes. The results revealed that the greatest values for all studied metals in the soft tissues of $C$. glaucum occurred during winter and autumn seasons, while the least values were recorded during spring and summer seasons. $\mathrm{Mg}$ and $\mathrm{Fe}$ concentrations were significantly higher in all seasons when compared with all other metals. The concentrations of metals, such as $\mathrm{Mn}, \mathrm{Ni}, \mathrm{Fe}$, and $\mathrm{Cr}$ were present beyond the WHO recommended standards, especially during winter and autumn seasons. Also, this study showed highly significant increase in lipid peroxidation (MDA) activity during autumn and winter seasons that was associated with a decrease in the mean activity levels of catalase (CAT) and glutathione peroxidase (GPx) than summer season and decrease in superoxide dismutase (SOD) activity than spring season. These results related to high heavy metals concentrations, such as $\mathrm{Cu}, \mathrm{Fe}$, and $\mathrm{Zn}$ during the autumn season, and $\mathrm{Mg}$, $\mathrm{Mn}, \mathrm{Cr}, \mathrm{Co}$, and $\mathrm{Ni}$ during the winter season. Moreover, the present study recorded positive significant correlations between MDA activity and $\mathrm{Cu}, \mathrm{Cr}$ and $\mathrm{Fe}$ concentrations, and significantly negative correlations between MDA activity and SOD activity, between CAT activity and Ni and Mn, and between GPx and $\mathrm{Mn}, \mathrm{Cr}$ and Fe. So, the present study suggests that MDA and antioxidant enzymes (CAT, GPx and SOD) can be used as biomarkers to reflect the level of heavy metal pollution stress, especially $\mathrm{Fe}$ and $\mathrm{Cr}$ in the soft tissues of $\mathrm{C}$. glaucum.

\section{INTRODUCTION}

The lagoon cockle Cerastoderma glaucum (Cardiidae) (Bruguière, 1789) represented one of the most dominant macrobenthos species living in Temsah Lake that plays an important role in most of the activities in Ismailia City (El-Din and El-Hak, 2017; Kandeel et al., 2017). It is eaten by a human, and considered a very cheap food resource due to their occurrence in high densities in this lake. It can share in the food 
chain as some marine animals prey upon them (Malham et al., 2012). But, these cockles, like the other bivalve species, are sedentary filter-feeding organisms (Hamza-Chaffai, 2014). They can bioaccumulate chemical contaminants in their tissues to a much higher level than those of the surrounding seawater (Zannella et al., 2017).

One of the threats to Temsah Lake ecosystem is heavy metal pollution (Ibrahim and El-Regal, 2014). Heavy metals originate from a number of anthropogenic and natural sources (El-Nemr et al., 2012). There are three major sources responsible for the heavy metal contamination in Temsah Lake namely; agricultural runoff, industrial discharge from shoreline workshops and raw sewage effluent from the city network (Abd El-Azim et al., 2018). Some heavy metals have a negative effect on many marine bivalve species, and consequently can cause a human health risk, especially when they are eaten raw or slightly cooked (Holland et al., 2015).

Heavy metals that are accumulated inside bivalve tissues may induce oxidative stress leading to lipid peroxidation, enzyme inactivation, protein degradation and DNA damage (Xu et al., 1999; Regoli, 2000). Hence, they can alter the cell membrane structure by stimulating lipid peroxidation of poly-unsaturated lipids leading to the intracellular generation of reactive oxygen species (ROS) and short-chain compounds like malondialdehydes (MDA) (Halliwell and Gutteridge, 2015). However, bivalves have developed defense mechanisms against these free radicals and ROS production to survive under these adverse conditions, including changes in respiratory and metabolic rates, activation of alternative pathways for energy production and induction of antioxidant defense and repair mechanisms (De Almeida et al., 2007). Where, the stimulation of lipid peroxidation is modulated by the presence of three major antioxidant enzymes [catalase (CAT), glutathione peroxidase (GPx) and superoxide dismutase (SOD)] that responsible for the detoxification process of ROS, and play a crucial role in maintaining cell homeostasis (Cantú-Medellín et al., 2009). CAT is a marker enzyme for oxidative stress in bivalves, and is involved in the breakdown of hydrogen peroxide $\left(\mathrm{H}_{2} \mathrm{O}_{2}\right)$ to molecular oxygen $\left(\mathrm{O}_{2}\right)$ and water (Regoli et al., 1998a, 1998c). GPx reduces both $\mathrm{H}_{2} \mathrm{O}_{2}$ and lipid hydroperoxides by coupling its reduction with the oxidation of glutathione (GSH) (Vinodhini and Narayanan, 2008). The conjugation reaction of the sulphydril group of GSH with the electrophilic group of xenobiotic compounds and toxins, catalyzed by glutathione-S-transferase (GST), makes the reaction products less toxic and more hydrosoluble for facilitating the excretion (Wiegand and Pflugmacher, 2005). SOD decomposes superoxide anion radical $\left(\mathrm{O}_{2}{ }^{\circ-}\right)$ to the less reactive species $\mathrm{H}_{2} \mathrm{O}_{2}$ and $\mathrm{O}_{2}$ (Regoli et al., 1998a, 1998c). So, the present study aims to investigate the relationships between MDA, CAT, GPx and SOD activities and heavy metals pollution in the soft tissues of $C$. glaucum to evaluate the physiological status of these cockles during the four different seasons.

\section{MATERIALS AND METHODS}

\section{Study area and sample collection}

Specimens of $C$. glaucum were seasonally collected during the period from autumn, 2017 to summer, 2018 from Temsah Lake, Ismailia, Egypt. The lake is small and shallow, situates between $30^{\circ} 33^{\prime} 3^{\prime \prime}$ and $30^{\circ} 35^{\prime} 31^{\prime \prime} \mathrm{N}$ latitude and $32^{\circ} 16^{\prime} 30^{\prime \prime}$ and $32^{\circ} 18^{\prime}$ 50" E longitude (Kandeel, 2018) (Fig. 1). It is characterized by receiving a variety of water types; saline water from the Suez Canal, and freshwater from the overflow of the 
Ismailia freshwater Canal (El-Sherbiny et al., 2011). Sorting of these bivalves from the sediments was occurred by sieve; its mesh size was $4 \mathrm{~mm}$. The animals with a standardized shell size $(31.58 \times 18.67 \times 25.02 \mathrm{~mm})$ were collected in polyethylene bags and freeze-dried as a whole in isothermal boxes.

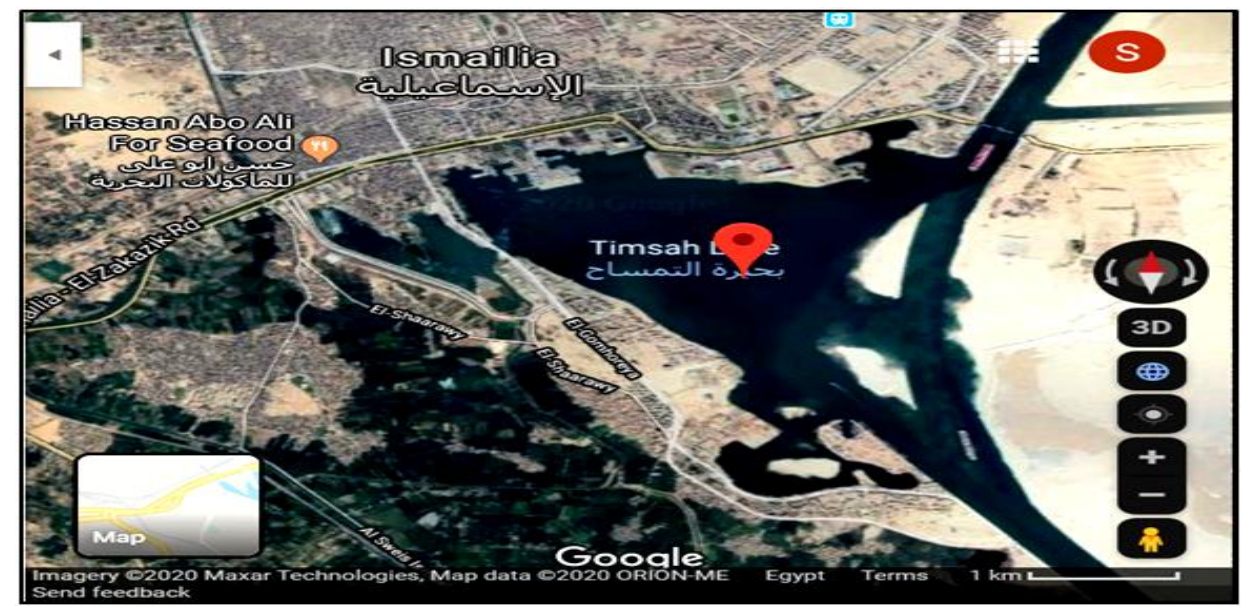

Fig. 1. A map of Temsah Lake, Ismailia, Egypt (Google map).

\section{Determination of heavy metals concentrations in the soft tissues of . glaucum}

Levels of heavy metals [copper $(\mathrm{Cu})$, iron $(\mathrm{Fe})$, magnesium $(\mathrm{Mg})$, manganese $(\mathrm{Mn})$, zinc $(\mathrm{Zn})$, chromium $(\mathrm{Cr})$, nickel $(\mathrm{Ni})$, cobalt $(\mathrm{Co})$, cadmium $(\mathrm{Cd})$ and lead $(\mathrm{Pb})]$ were determined according to Manutsewee et al. (2007). An aliquot of the soft tissues of cockles was dried at $70{ }^{\circ} \mathrm{C}$ for enough time until ashed. The digestion of samples was occurred using a digestion mixture containing conc. $\mathrm{HNO}_{3}, \mathrm{HCl}$ and $\mathrm{H}_{2} \mathrm{O}_{2}$. The samples were analyzed by Inductively Coupled Plasma Optical Emission Spectrometer (ICP-OES; Agilent $5100 \mathrm{VDV}$ ). The obtained results were expressed as $\mu \mathrm{g} / \mathrm{g}$ dry weight. Working standards were used, and quality assurance procedures and precautions were carried out to ensure the reliability of the results. Samples were carefully handled, and deionized water was used to avoid contamination.

\section{Biochemical analysis in the soft tissues of $C$. glaucum}

The tissues were homogenized in $5-10 \mathrm{ml}$ cold buffer per gram tissue. The homogenated tissue was then centrifuged at $4000 \mathrm{rpm}$ for $15 \mathrm{~min}$ at $4{ }^{\circ} \mathrm{C}$. Only for SOD assay, $0.5 \mathrm{ml}$ of ice-cold extraction reagent (ethanol/chloroform 60/40 v/v) was added to 1 $\mathrm{ml}$ of supernatant, vortexed for at least $30 \mathrm{sec}$, and centrifuged again at $4000 \mathrm{rpm}$ for 10 min at $4{ }^{\circ} \mathrm{C}$. The resulting supernatant containing the enzyme was separated, and should be stored at 0-4 $\mathrm{C}$ until used for the assay. Enzymes activities were analyzed by colorimetric method. Determination of lipid peroxidation (MDA) activity was measured according to Kei (1978), Ohkawa et al. (1979) and Persky et al. (2000). The CAT activity was determined by the method of Fossati et al. (1980) and Aebi (1984). The GPx levels were determined by the method of Paglia and Valentine (1967). The SOD activity was measured using the procedure of Nishikimi et al. (1972). 


\section{Statistical analysis}

All experiments were conducted three times. Data were represented as mean \pm standard deviations (SD). Statistical analyses by one-way analysis of variance (ANOVA) and Pearson's linear correlation coefficient (r) test were used. Significant differences were considered when $p \leq 0.05$.

\section{RESULTS}

\section{Seasonal heavy metals concentrations in the soft tissues of $\boldsymbol{C}$. glaucum}

The data in Table 1 demonstrate that most heavy metals concentrations were high during winter and autumn seasons when compared with spring and summer seasons. The determined metals recorded high accumulation of $\mathrm{Mg}, \mathrm{Mn}, \mathrm{Cr}$, Ni and Co (1211.97, $1.973,13.856,8.436$ and $0.276 \mu \mathrm{g} . \mathrm{g}^{-1}$, respectively) during winter than all other seasons. While, concentrations of $\mathrm{Cu}, \mathrm{Fe}$ and $\mathrm{Zn}\left(1.125,114.589\right.$ and $17.83 \mu \mathrm{g} . \mathrm{g}^{-1}$, respectively) were high during autumn. The results showed a complete absence of $\mathrm{Cd}$ and $\mathrm{Pb}$ from $C$. glaucum tissues during all seasons. The results in Figure 2 revealed that $\mathrm{Mg}$ and $\mathrm{Fe}$ concentrations were significantly higher in all seasons when compared with all other metals $(P=0.000)$, while $\mathrm{Co}$ and $\mathrm{Cu}$ concentrations were significantly lower in all seasons comparing with $\mathrm{Fe}, \mathrm{Mg}$ and $\mathrm{Zn}(P=0.000)$.

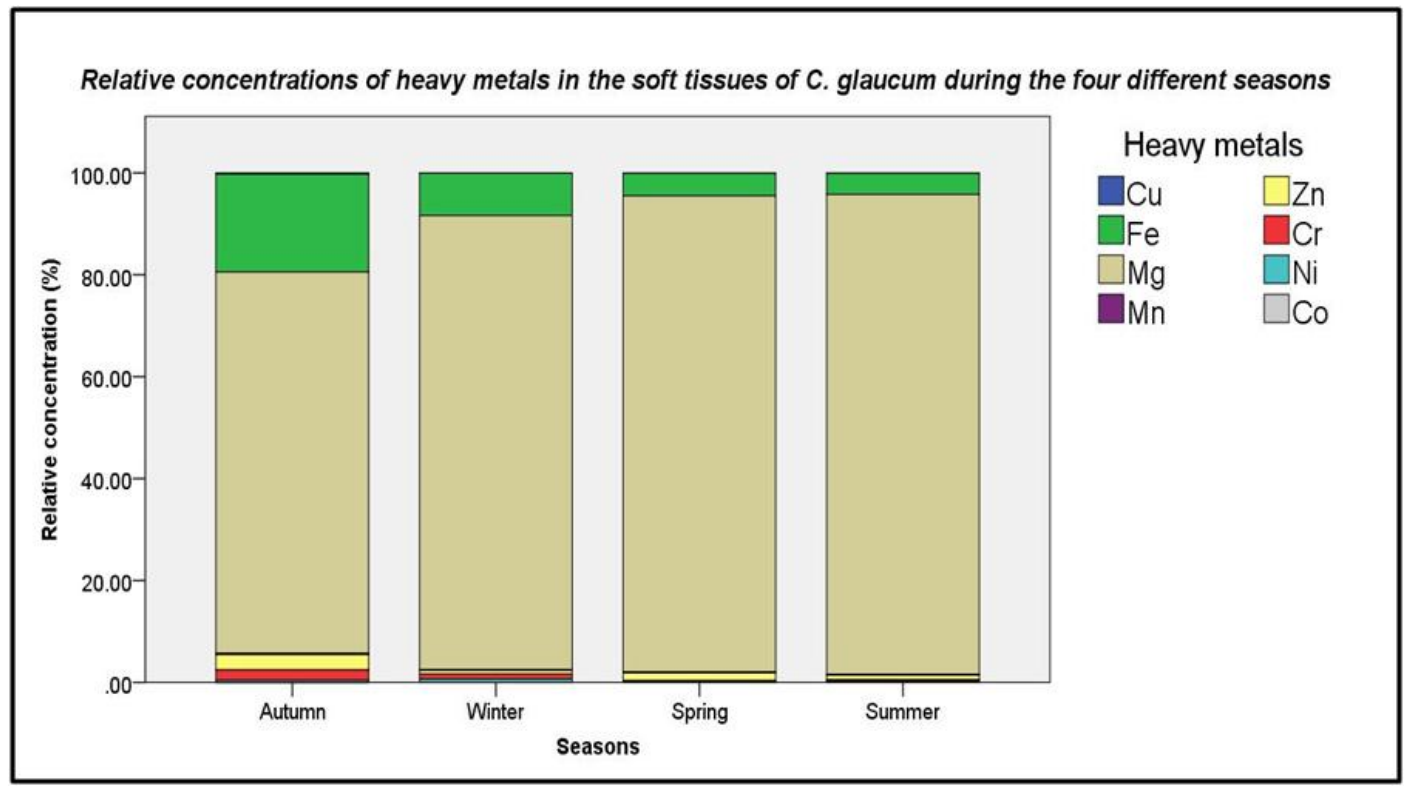

Fig. 2. Relative concentrations of heavy metals in the soft tissues of $C$. glaucum during the four different seasons. 
Table 1. Heavy metals concentrations $\left(\mu \mathrm{g} . \mathrm{g}^{-1} d r y w\right.$.) in the soft tissues of $C$. glaucum during the four different seasons. Data are means \pm SD. Means in the same column with different superscript letters ${ }^{(a, b, c \text { and } d)}$ are significantly different, $P<0.05$ (one-way ANOVA).

\begin{tabular}{|c|c|c|c|c|c|c|c|c|c|c|}
\hline \multirow[t]{2}{*}{ Seasons } & \multicolumn{10}{|c|}{ Concentration $\left(\mu \mathrm{g} \cdot \mathrm{g}^{-1}\right)$} \\
\hline & $\mathrm{Cu}$ & $\mathbf{F e}$ & Mg & Mn & $\mathbf{Z n}$ & $\mathrm{Cr}$ & $\mathbf{N i}$ & Co & Cd & $\mathbf{P b}$ \\
\hline Autumn & $1.125 \pm 0.001^{b^{*}}$ & $114.589 \pm 1.2^{\mathrm{c}}$ & $445.014 \pm 4^{\mathrm{a}^{* * * *}}$ & $1.819 \pm 0.02^{b^{*}}$ & $17.83 \pm 1.3^{\mathrm{c}^{* * * *}}$ & $12.063 \pm 0.1^{\mathrm{c}^{* * * *}}$ & $2.48 \pm 0.02^{\mathrm{c} * *}$ & ND & ND & $\mathrm{ND}$ \\
\hline Winter & $0.799 \pm 0.02^{\mathrm{a}}$ & $113.169 \pm 1.1^{\mathrm{c}}$ & $1211.97 \pm 5.03^{\mathrm{d}}$ & $1.973 \pm 0.1^{\mathrm{c}}$ & $9.591 \pm 0.6^{\mathrm{a}}$ & $13.856 \pm 0.2^{\mathrm{d}}$ & $8.436 \pm 0.04^{\mathrm{d}}$ & $0.276 \pm 0.03^{\mathrm{c}}$ & ND & ND \\
\hline Spring & $0.795 \pm 0.03^{\mathrm{a}}$ & $40.185 \pm 0.2^{\mathrm{a}^{* * *}}$ & $852.337 \pm 2.3^{\mathrm{b}^{* * *}}$ & $1.724 \pm 0.01^{\mathrm{b}^{* *}}$ & $13.96 \pm 1.4^{\mathrm{b}^{* *}}$ & $1.351 \pm 0.04^{\mathrm{a}^{* * *}}$ & $1.554 \pm 0.01^{\mathrm{a}^{* * *}}$ & $0.04 \pm 0.02^{\mathrm{a}^{* * * *}}$ & ND & ND \\
\hline Summer & $0.754 \pm 0.2^{\mathrm{a}}$ & $43.011 \pm 1.2^{\mathrm{b}^{* * *}}$ & $977.18 \pm 3.1^{\mathrm{c} * * *}$ & $1.17 \pm 0.02^{\mathrm{a}^{* * *}}$ & $9.176 \pm 0.7^{\mathrm{a}}$ & $3.489 \pm 0.02^{\mathrm{b}^{* * *}}$ & $1.995 \pm 0.03^{\mathrm{b}^{* * *}}$ & $0.128 \pm 0.01^{\mathrm{b}^{* * *}}$ & ND & ND \\
\hline Seasonal mean & $0.868 \pm 0.178$ & $77.738 \pm 37.775$ & $871.625 \pm 290.477$ & $1.671 \pm 0.319$ & $12.639 \pm 3.8$ & $7.689 \pm 5.6$ & $3.616 \pm 2.926$ & $0.111 \pm 0.111$ & & \\
\hline F ratio & 8.633 & 5064.934 & 22017.124 & 134.648 & 44.422 & 8844.154 & 41869.841 & 128.217 & & \\
\hline P-value & 0.007 & 0.000 & 0.000 & 0.000 & 0.000 & 0.000 & 0.000 & 0.000 & & \\
\hline \multicolumn{11}{|c|}{ Maximum residual limits (MRLs; $\mu \mathrm{g} . \mathrm{g}^{-1}$ ) } \\
\hline $\begin{array}{l}\text { FAO/WHO } \\
\text { (1989) }\end{array}$ & 30 & 100 & - & 1 & $40-100$ & - & - & - & - & - \\
\hline WHO (1989) & 30 & 100 & - & 1 & 100 & - & $0.5-1$ & - & 1 & 2 \\
\hline US FDA (2001) & - & - & - & - & - & $12-13$ & - & - & - & - \\
\hline
\end{tabular}

ND: Non detected. Each value is the mean of 3 replicates \pm SD (Standard Deviation), F ratio: Frequency and P-value: Probability. Maximum residual limits (MRLs) were according to FAO/WHO (1989), WHO (1989) and US FDA (2001).

*Significant at $\mathrm{P}$-value $\leq 0.05, * *$ Significant at $\mathrm{P}$-value $\leq 0.01$ and *** Significant at $\mathrm{P}$-value $\leq 0.001$. 


\section{Biochemical analysis in the soft tissues of . . glaucum}

As shown in Figure 3, there were highly significant seasonal variations in the activities of lipid peroxidation (MDA) and antioxidant enzymes, such as CAT, GPx and SOD $(P=0.000)$. The highly significant increase in MDA activity was observed during autumn season than all other seasons $(P=0.000)$. The mean activity levels of CAT and GPx in summer season were higher than all other seasons $(P \leq 0.039$ and $P=0.000$, respectively). While, the mean activity level of SOD in spring season was higher than all other seasons $(P=0.000)$.

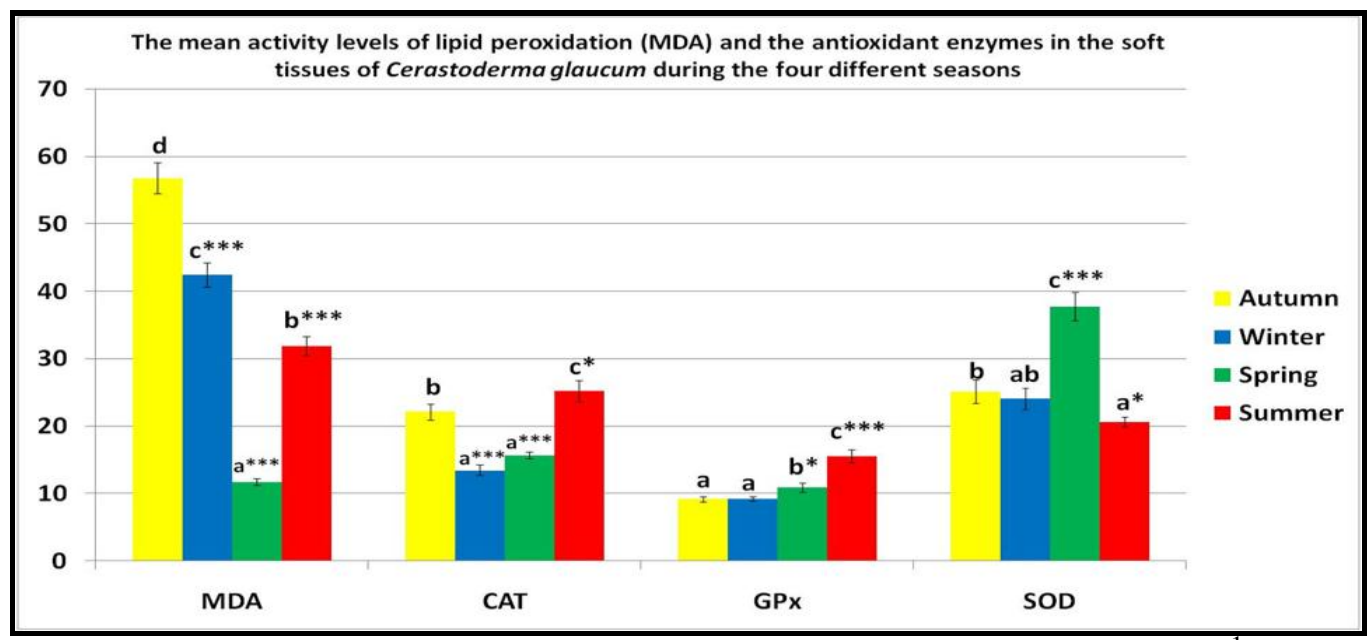

Fig. 3. The mean activity levels of lipid peroxidation (MDA, nmol. $\mathrm{g}^{-1}$ tissue) and the antioxidant enzymes ( $\mathrm{U}^{-1} \mathrm{~g}^{-1}$ tissue) in the soft tissues of $C$. glaucum during the four different seasons. Values are mean \pm SD. Different letters ${ }^{(a, b, c \text { and } d)}$ are significant, $P<$ 0.05 (one-way ANOVA).

\section{Pearson linear correlation analysis}

Figure 4 presents the Pearson linear correlation of MDA and antioxidant enzyme activities with the concentrations of different heavy metals in the soft tissues of $C$. glaucum collected throughout the study period. The positive significant correlations were found between MDA activity and $\mathrm{Cu}\left(r=0.645^{*}\right), \mathrm{Cr}\left(r=0.855^{* *}\right)$ and $\mathrm{Fe}\left(r=0.861^{* *}\right)$ concentrations. Also, MDA activity was negatively correlated with SOD activity $(r=-$ $0.685^{*}$ ). The mean activity level of CAT in the soft tissues of $C$. glaucum showed a significant positive correlation with GPx activity $\left(r=0.672^{*}\right)$ and significant negative correlations with $\mathrm{Ni}\left(r=-0.618^{*}\right)$ and $\mathrm{Mn}\left(r=-0.771^{* *}\right)$. The significantly negative correlations were reported between GPx activity and concentrations of Mn $\left(r=-0.969^{* *}\right)$, $\mathrm{Cr}\left(r=-0.660^{*}\right)$ and $\mathrm{Fe}\left(r=-0.745^{* *}\right)$. 


\section{Matrix plot of MDA, CAT, GPX, SOD, Cu, Co, Ni, Mn, $\mathrm{Cr}, \mathrm{Fe}, \mathrm{Mg}$ and Zn Pearson linear correlation}

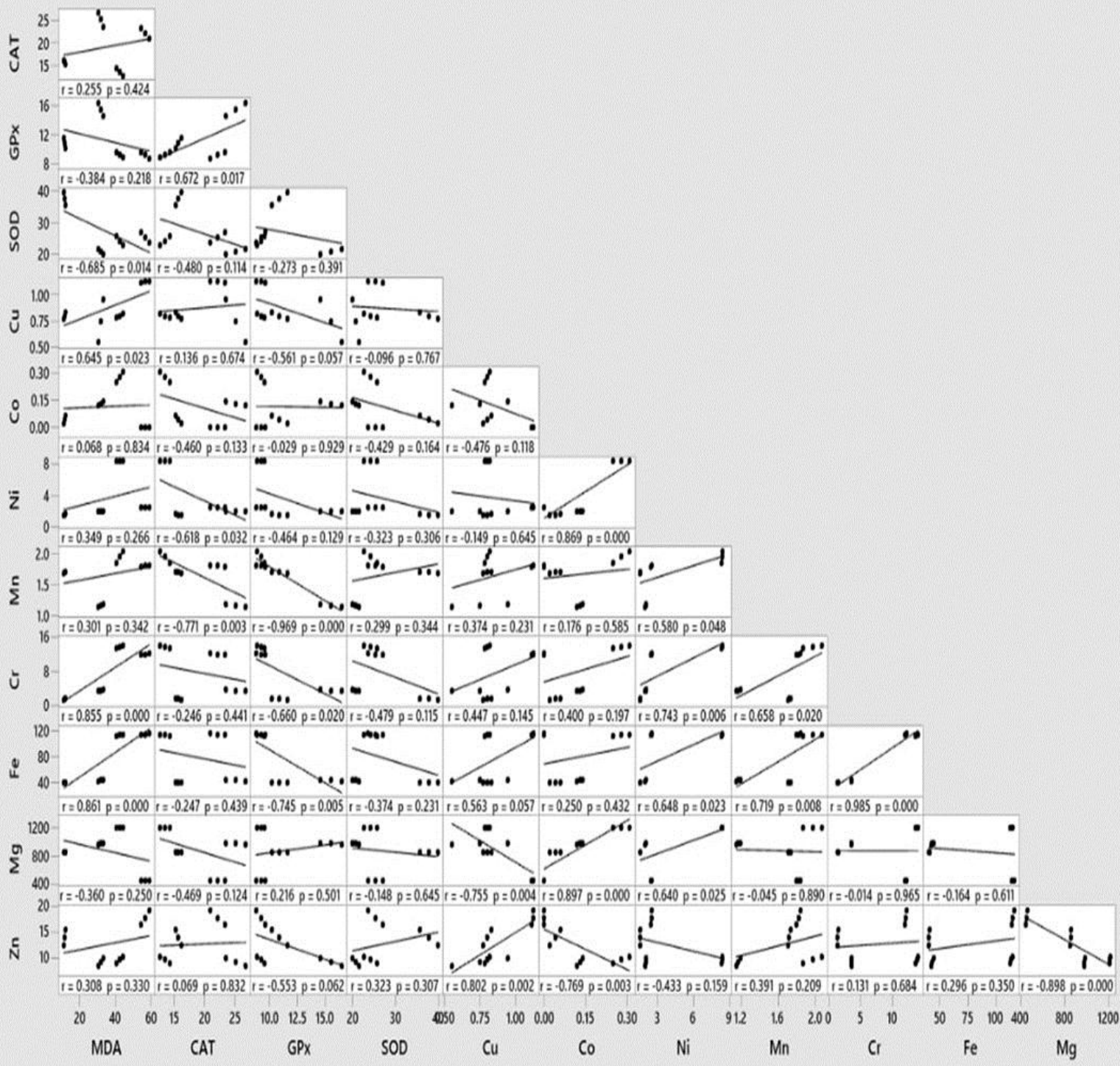

Fig. 4. Pearson linear correlation coefficient (r) of lipid peroxidation (MDA) and antioxidant enzymes (CAT, GPx and SOD) activities with the concentrations of different heavy metals in the soft tissues of Cerastoderma glaucum collected throughout the study period. P: $*$ Correlation is significant at the $\leq 0.05$ level and $* *$ Correlation is significant at the $\leq 0.01$ level (2-tailed). 


\section{DISCUSSION}

Environmental pollution due to heavy metals represents a serious marine problem around the world (Cajaraville $\boldsymbol{e t}$ al., 2000). They are dangerous due to its high toxicity, persistence and bioaccumulation ability of these metals in tissues of the living organisms (Sharaf and Shehata, 2015). The consumption of seafood contaminated by heavy metals can lead to potential human hazards. This study was carried out to reveal the seasonal levels of heavy metals in the edible marine bivalve $C$. glaucum collected from Temsah Lake. The present study revealed that there were significant seasonal variations in the concentrations of heavy metals in the soft tissues of $C$. glaucum collected from Temsah Lake. Where the maximal levels of heavy metals were recorded during winter and autumn seasons, and the minimal ones were registered during spring and summer seasons. The seasonal variation of the metal levels in Temsah Lake is due to the agriculture effluents, industrial waste products through shipyard of the Suez Canal and municipal waste products through sewage discharge from Ismailia city (Abd El-Azim, 2002). These data are in the same line with studies demonstrating the influence of seasons on metal accumulation in the bivalve species (Chafik $\boldsymbol{e t}$ al., 2001; Rouane-Hacene $\boldsymbol{e t}$ al., 2015), as they recorded the highest levels of metals during winter season and the lowest levels during summer season. Also, Pestana et al. (2009) suggested that during wet seasons, bivalves take a longer time for clearing their intestinal tract from contaminated heavy meals than in dry seasons.

This finding appeared that seasonal variation in heavy metals concentrations was not only affected by changes in temperature or physical parameters, but strongly affected by a seasonal variation of human activities and discharges into Temsah Lake. Whereas, the heavy metals may find their way into Temsah Lake with rainwater and sewage (Abd ElAzim, 2002). Also, the fishing activities at Temsah Lake are increased in the rainy seasons (Alam et al., 2003).

Current results revealed the highest concentrations of $\mathrm{Mg}$ and $\mathrm{Fe}$ and the lowest concentrations of $\mathrm{Co}$ and $\mathrm{Cu}$ in $C$. glaucum soft tissues throughout all seasons. This result may be due to increasing these metals into the lake. These findings are in agreement with previous observations recorded by Ibrahim and El-Regal (2014), Sharaf and Shehata (2015) and Abd El-Azim et al. (2018) who studied the heavy metals concentrations in Temsah Lake, and found that $\mathrm{Fe}$ and $\mathrm{Mg}$ reached the maximum values in the water samples of Temsah Lake and the soft tissues of the studied bivalve species.

Heavy metals concentrations in $C$. glaucum soft tissues remain within acceptable limits proposed by FAO/WHO (1989) and WHO (1989) for consumption, except for Mn and $\mathrm{Ni}$ in all seasons and $\mathrm{Fe}$ only in autumn and winter seasons were upper the permissible limits. Also, $\mathrm{Cr}$ content during winter season was slightly greater than the limit set by US FDA (2001).

There is a close relationship between environmental stress in bivalves and the rate of cellular reactive oxygen species (ROS) generation (Storey, 1996). When the rate of ROS production exceeds the rate of its decomposition by antioxidant defenses and repair systems, oxidative stress can be established by ROS leading to several toxic processes, including DNA damage, chemical carcinogenesis, lipid peroxidation activation and enzymatic inactivation, especially CAT, GPx and SOD (Sies, 1993; Bagchi et al., 1995; Cheung et al., 2001). The activities of these antioxidant enzymes serve as protective 
responses to eliminate reactive free radicals (Karakoc $\boldsymbol{e t}$ al., 1997; Solé $\boldsymbol{e t}$ al., 1998). MDA and these antioxidative enzymes have been detected in a number of bivalve species (Regoli et al., 1998a, 1998c; Cheung et al., 2002; Charissou et al., 2004).

In the present study, the highly significant increase in lipid peroxidation (MDA) activity during autumn and winter seasons was associated with a decrease in the mean activity levels of CAT and GPx than summer season and decrease in SOD activity than spring season. These results can be explained by high heavy metals concentrations, such as $\mathrm{Cu}, \mathrm{Fe}$ and $\mathrm{Zn}$ during autumn season and $\mathrm{Mg}, \mathrm{Mn}, \mathrm{Cr}$, Co and $\mathrm{Ni}$ during winter season than spring and summer seasons. Hence, the present study showed the positive significant correlations between MDA activity and $\mathrm{Cu}, \mathrm{Cr}$ and $\mathrm{Fe}$ concentrations and significantly negative correlation between MDA activity and SOD activity. These results are confirmed with that observed by El-Khodary et al. (2018) who recorded an increase in the mean activity level of MDA 17.93 (U/g) in the soft tissue of Ruditapes decussatus collected from Abo Quir Bay, where heavy metal toxicity increased, associated with a significant decrease of SOD and GPx activities. Cantú-Medellín et al. (2009) showed a positive correlation between thiobarbituric acid reactive substance (TBARS) level and $\mathrm{Cu}$ concentration in muscle tissue of the black chocolate clam Megapitaria squalid at El Mogote $(r=0.94)$.

In marine bivalves, exposure to metals induces oxidative stress through the formation of ROS and lipid peroxidation (De Almeida et al., 2004). $\mathrm{Cu}$ can induce oxyradicals (superoxide radicals) production leading to MDA formation (Gómez-Mendikute and Cajaraville, 2003), and this has been demonstrated in Mytilus galloprovincialis (Viarengo et al., 1990, 1991), Crassostrea virginica (Ringwood et al., 1998), C. gigas and M. edulis (Géret et al., 2002) and Perna perna (De Almeida et al., 2004). Also, transition metals, such as Fe catalyze the reaction of superoxide anion radicals with hydrogen peroxide to produce hydroxyl radicals by Fenton reactions (Sies, 1988; Winston and DiGiulio, 1991). These hydroxyl radicals attack polyunsaturated fatty acids to produce lipid hydroperoxides (Cheung et al., 2002). Viarengo et al. (1990) showed a relationship between metal exposure, especially $\mathrm{Fe}, \mathrm{Cu}, \mathrm{Co}, \mathrm{Cd}$ and $\mathrm{Al}$ and lipid peroxidation in bivalves. Also, $\mathrm{Fe}$ and $\mathrm{Cd}$ alter the structure of cell membranes by stimulating lipid peroxidation of polyunsaturated lipids forming epoxides, hydroperoxides, epoxyalcohols, hydroxyalkenals and short-chain compounds like MDA (Stohs et al., 2000).

The present study recorded a significant positive correlation of CAT activity with GPx level. Also, it presented significantly negative correlations between CAT activity and $\mathrm{Ni}$ and Mn concentrations, and between GPx activity and $\mathrm{Mn}, \mathrm{Cr}$ and Fe concentrations. Different responses of the antioxidant enzymes have been demonstrated in bivalves subjected to chronic or acute exposure of different levels of heavy metals (Regoli and Principato, 1995). Previous studies on the responses to pollutants indicated the partial inhibition of GPx activity as a general response to metal exposure in bivalves (Regoli et al., 1998b). Metals, such as $\mathrm{Fe}$ and $\mathrm{Cu}$ under acute exposure, can decrease GPx activity level, and to produce lipid peroxidation in P. perna (De Almeida et al., 2004). Activities of GPx and SOD activities in Macoma balthica and Adamussium colbecki exhibited negative relationships with $\mathrm{Fe}$ and $\mathrm{Cr}$ concentrations and a positive correlation with $\mathrm{Zn}$ level (Regoli et al., 1998a, 1998c). A negative correlation was found between the level of $\mathrm{Ni}$ concentration and SOD activity in muscle tissue of Megapitaria squalida from Playa 
El Sausozo ( $r=-0.99)$ (Cantú-Medellín et al., 2009). The negative correlations between the unnaturally high pollutant concentrations and some of the enzymatic antioxidant activities may be due to the inhibitory effects caused by these chemicals (Cheung $\boldsymbol{e t}$ al., 2001). Also, the occurrence of one kind of antioxidant enzyme response or more depends on the exposure time, toxicant concentration and bivalve species (Bebianno et al., 2005).

\section{CONCLUSION}

In conclusion, the present study suggests that $C$. glaucum is at a great risk of $\mathrm{Mn}$, $\mathrm{Ni}, \mathrm{Fe}$ and $\mathrm{Cr}$, especially during winter and autumn seasons, since these metals concentrations were present beyond the WHO recommended standards in the edible part. Also, the lipid peroxidation (MDA) and antioxidant enzymes (CAT, GPx and SOD) activities are affected by heavy metals pollution, and have potential as indicators of heavy metal contamination, especially $\mathrm{Fe}$ and $\mathrm{Cr}$ in the soft tissues of the marine bivalve $C$. glaucum.

\section{REFERENCES}

Abd El-Azim, H. (2002). Heavy metals in Suez Canal relevant to the impacts of landbased sources. Ph. D. Thesis, Chem. Depart., Fac. Sci., El-Mansoura Univ., Egypt.

Abd El-Azim, H. A.; Belal, A. A.; El-Salam, E. T. A.; Mourad, F. A. and Elwafa, S. Y. A. (2018). Water pollution by heavy metals in the western lagoon and its effect on Timsah Lake and consequently on Suez Canal. ESES., 17(1): 71-76.

Aebi, H. (1984). Catalase in vitro. Methods in Enzymology, Academic Press, New York, 105(5): 121-126.

Alam, A. M.; Islam, M. A.; Rahman, M. A.; Siddique, M. N. and Matin, M. A. (2003). Comparative study of the toxic metals and non-metal status in the major river system of Bangladesh. Dhaka Univ. J. Sci., 51(2): 201-208.

Bagchi, D.; Hassoun, E. A.; Bagchi, M. and Stohs, S. J. (1995). Protective effects of free radical scavengers and antioxidants against smokeless tobacco extract (STE)induced oxidative stress in macrophage J774A. 1 cell cultures. Arch. Environ. Con. Tox., 29(3): 424-428.

Bebianno, M. J.; Serafim, A.; Camus, L.; Cosson, R. P. and Fiala-Medoni, A. (2005). Antioxidant systems and lipid peroxidation in Bathymodiolus azoricus from MidAtlantic Ridge hydrothermal vent fields. Aquat. Toxicol., 75(4): 354-373.

Bruguière, J. G. (1789). Encyclopédie méthodique ou par ordre de matières; par une société de gens de lettres, de savans et d'artistes Histoire naturelle des vers. 1. Tome sixieme: Paris, chez Panckoucke, libraire, Liege, chez Plomteux, Imprimeur des Etats, 1: $1-344$.

Cajaraville, M. P.; Bebianno, M. J.; Blasco, J.; Porte, C.; Sarasquete, C. and Viarengo, A. (2000). The use of biomarkers to assess the impact of pollution in coastal environments of the Iberian Peninsula: A practical approach. Sci. Total Environ., 247(2-3): 295-311.

Cantú-Medellín, N.; Olguín-Monroy, N. O.; Méndez-Rodríguez, L. C. and ZentenoSavín, T. (2009). Antioxidant enzymes and heavy metal levels in tissues of the black 
chocolate clam Megapitaria squalida in Bahia de La Paz, Mexico. Arch. Environ. Con. Tox., 56(1): 60-66.

Chafik, A.; Cheggour, M.; Cossa, D.; Benbrahim, S. and Sifeddine, M. (2001). Quality of Moroccan Atlantic coastal water monitoring and mussel watching. Aquat. Living Resour., 14(4): 239-249.

Charissou, A. M.; Cossu-Leguille, C. and Vasseur, P. (2004). Relationship between two oxidative stress biomarkers, malondialdehyde and 8-oxo-7, 8-dihydro-2'deoxyguanosine, in the freshwater bivalve Unio tumidus. Sci. Total Environ., 322(13): 109-122.

Cheung, C. C. C.; Zheng, G. J.; Lam, P. K. S. and Richardson, B. J. (2002). Relationships between tissue concentrations of chlorinated hydrocarbons (polychlorinated biphenyls and chlorinated pesticides) and antioxidative responses of marine mussels, Perna viridis. Mar. Pollut. Bull., 45(1-12): 181-191.

Cheung, C. C. C.; Zheng, G. J.; Li, A. M. Y.; Richardson, B. J. and Lam, P. K. S. (2001). Relationships between tissue concentrations of polycyclic aromatic hydrocarbons and antioxidative responses of marine mussels, Perna viridis. Aquat. Toxicol., 52(3-4): 189-203.

De Almeida, E. A.; Bainy, A. C. D.; de Melo Loureiro, A. P.; Martinez, G. R.; Miyamoto, S.; Onuki, J. and Sigolo, C. A. (2007). Oxidative stress in Perna perna and other bivalves as indicators of environmental stress in the Brazilian marine environment: Antioxidants, lipid peroxidation and DNA damage. Comp. Biochem. Phys. A, 146(4): 588-600.

De Almeida, E. A.; Miyamoto, S.; Bainy, A. C. D.; de Medeiros, M. H. G. and Di Mascio, P. (2004). Protective effect of phospholipid hydroperoxide glutathione peroxidase (PHGPx) against lipid peroxidation in mussels Perna perna exposed to different metals. Mar. Pollut. Bull., 49(5-6): 386-392.

El-Din, M. I. S. and El-Hak, H. N. G. (2017). Impact of heavy metals contamination on spring abundance of aquatic macro-invertebrates inhabiting Lake Timsah, Egypt. JWS., (3): 2345-10363.

El-Khodary, G. M.; Radwan, E. H.; El-Ghazaly, M. M. and El-Bahnasawy, D. (2018). Marine pollution by some heavy metals and physiological response of Ruditapes decussatus. JBAAR., 4(3): 199-217.

El-Nemr, A.; Khaled, A.; Moneer, A. and El-Sikaily, A. (2012). Risk probability due to heavy metals in bivalve from Egyptian Mediterranean coast. EJAR., 38(2): 67-75.

El-Sherbiny, M. M.; AL-Aidaroos, A. M. and Gab-Alla, A. (2011). Seasonal composition and population density of zooplankton in Lake Timsah, Suez Canal, Egypt. Oceanologia, 53(3): 837-859.

FAO/WHO (1989). National research council recommended dietary allowances, 10 th ed. National Academy Press, Washington, DC. USA.

Fossati, P.; Prencipe, L. and Berti, G. (1980). Use of 3, 5-dichloro-2hydroxybenzenesulfonic acid/4-aminophenazone chromogenic system in direct enzymic assay of uric acid in serum and urine. Clin. Chem., 26(2): 227-231.

Géret, F.; Jouan, A.; Turpin, V.; Bebianno, M. J. and Cosson, R. P. (2002). Influence of metal exposure on metallothionein synthesis and lipid peroxidation in two bivalve mollusks: The oyster (Crassostrea gigas) and the mussel (Mytilus edulis). Aquat. Living Resour., 15(1): 61-66. 
Gómez-Mendikute, A. and Cajaraville, M. P. (2003). Comparative effects of cadmium, copper, paraquat and benzo[a]pyrene on the actin cytoskeleton and production of reactive oxygen species (ROS) in mussel haemocytes. Toxicol. In Vitro, 17(5-6): 539-546.

Halliwell, B. and Gutteridge, J. M. (2015). Free radicals in biology and medicine. Oxford Univer. Press, USA.

Hamza-Chaffai, A. (2014). Usefulness of bioindicators and biomarkers in pollution biomonitoring. Int. J. Biotechnol. Wellness. Ind., 3(1): 19-26.

Holland, J.; Brereton, N.; Fernandes, A. and Rose, M. (2015). Chemical contaminant sampling and analysis of shellfish from classified harvesting areas. Rep. to Food Standards Agency Northern Ireland.

Ibrahim, N. K. and El-Regal, M. A. A. (2014). Heavy metals accumulation in marine edible molluscs, Timsah Lake, Suez Canal, Egypt. ARPN J. Sci. Technol., 4(4): 282288.

Kandeel, K. E. S. (2018). Population dynamics of Venerupis aurea (Bivalvia: Veneridae) in two different clam's beds in Lake Timsah, Suez Canal, Egypt. Thalassia Salentina, 40: 67-94.

Kandeel, K. E.; Mohammed, S. Z.; Mostafa, A. M. and Abd-Alla, M. E. (2017). Population dynamics of the cockle Cerastoderma glaucum: A comparison between lake Qarun and lake Timsah, Egypt. Turk. J. Fish. Aquat. Sc., 17(5): 945-958.

Karakoc, F. T.; Hewer, A.; Philips, D. H.; Gaines, A. F. and Yuregir, G. (1997). Biomarkers of marine pollution observed in species of mullet living in two eastern Mediterranean harbours. Biomarkers, 2(5): 303-309.

Kei, S. (1978). Serum lipid peroxide in cerebrovascular disorders determined by a new colorimetric method. Clin. Chim. Acta, 90(1): 37-43.

Malham, S. K.; Hutchinson, T. H. and Longshaw, M. (2012). A review of the biology of European cockles (Cerastoderma spp.).. Mar. Biol. Assoc. UK., 92(7): 1563-1577.

Manutsewee, N.; Aeungmaitrepirom, W.; Varnusupakul, P. and Imyim, A. (2007). Determination of $\mathrm{Cd}, \mathrm{Cu}$, and $\mathrm{Zn}$ in fish and mussel by AAS after ultrasound-assisted acid leaching extraction. Food Chem., 101(2): 817-824.

Nishikimi, M.; Rao, N. A. and Yagi, K. (1972). The occurrence of superoxide anion in the reaction of reduced phenazine methosulfate and molecular oxygen. Biochem. Bioph. Res. Co., 46(2): 849-854.

Ohkawa, H.; Ohishi, N. and Yagi, K. (1979). Assay for lipid peroxides in animal tissues by thiobarbituric acid reaction. Anal. Biochem., 95(2): 351-358.

Paglia, D. E. and Valentine, W. N. (1967). Studies on the quantitative and qualitative characterization of erythrocyte glutathione peroxidase. J. Lab. Clin. Med., 70(1): 158-169.

Persky, A. M.; Greene, P. S.; Stubley, L.; Howell, C. O.; Zaulyanov, L.; Brazeau, G. A. and Simpkins, J. W. (2000). Protective effect of estrogens against oxidative damage to heart and skeletal muscle in vivo and in vitro (44463). Proc. Soc. Exp. Biol. Med., 223(1): 59-66.

Pestana, D.; Ostrensky, A.; Boeger, W. A. P. and Pie, M. R. (2009). The effect of temperature and body size on filtration rates of Limnoperna fortunei (Bivalvia, Mytilidae) under laboratory conditions. Braz. Arch. Biol. Techn., 52(1): 135-144. 
Regoli, F. (2000). Total oxyradical scavenging capacity (TOSC) in polluted and translocated mussels: A predictive biomarker of oxidative stress. Aquat. Toxicol., 50(4): 351-361.

Regoli, F. and Principato, G. (1995). Glutathione, glutathione-dependent and antioxidant enzymes in mussel, Mytilus galloprovincialis, exposed to metals under field and laboratory conditions: Implications for the use of biochemical biomarkers. Aquat. Toxicol., 31(2): 143-164.

Regoli, F.; Hummel, H.; Amiard-Triquet, C.; Larroux, C. and Sukhotin, A. (1998a). Trace metals and variations of antioxidant enzymes in Arctic bivalve populations. Arch. Environ. Con. Tox., 35(4): 594-601.

Regoli, F.; Nigro, M. and Bertoli, E. (1998b). Defenses against oxidative stress in the Antarctic scallop Adamussium colbecki and effects of acute exposure to metals. Ocean. Lit. Rev., 7(45): 1216.

Regoli, F.; Nigro, M. and Orlando, E. (1998c). Lysosomal and antioxidant responses to metals in the Antarctic scallop Adamussium colbecki. Aquat. Toxicol., 40(4): 375-392.

Ringwood, A. H.; Conners, D. E. and DiNovo, A. (1998). The effects of copper exposures on cellular responses in oysters. Mar. Environ. Res., 46(1-5): 591-595.

Rouane-Hacene, O.; Boutiba, Z.; Belhaouari, B.; Guibbolini-Sabatier, M. E.; Francour, P. and Risso-de Faverney, C. (2015). Seasonal assessment of biological indices, bioaccumulation and bioavailability of heavy metals in mussels Mytilus galloprovincialis from Algerian west coast, applied to environmental monitoring. Oceanologia, 57(4): 362-374.

Sharaf, H. M. and Shehata, A. M. (2015). Heavy metals and hydrocarbon concentrations in water, sediments and tissue of Cyclope neritea from two sites in Suez Canal, Egypt and histopathological effects. J. Environ. Health Sci. Eng., 13(1): 14-21.

Sies, H. (1988). Oxidative stress-quinone redox cycling. ISI Atlas of Sci. Biochem., 1(2): $109-114$.

Sies, H. (1993). Strategies of antioxidant defense. Eur. J. Biochem., 215(2): 213-219.

Solé, M.; Peters, L. D.; Magnusson, K.; Sjolin, A.; Granmo, A. and Livingstone, D. R. (1998). Responses of the cytochrome P450 dependent monooxygenase and other protective enzyme systems in digestive gland of transplanted common mussel Mytilus edulis L. to organic contaminants in the Skagerrak and Kattegat (North Sea). Biomarkers, 3(1): 49-62.

Stohs, S. J.; Bagchi, D.; Hassoun, E. and Bagchi, M. (2000). Oxidative mechanisms in the toxicity of chromium and cadmium ions. J. Environ. Pathol., Tox. Oncol., 19(3): 201-213.

Storey, K. B. (1996). Oxidative stress: Animal adaptations in nature. Braz. J. Med. Biol. Res., 29: 1715-1733.

US FDA (2001). Fish and fisheries products hazards and controls guidance, third ed. Center for Food Safety and Applied Nutrition, US Food and Drug Administration, Washington, DC.

Viarengo, A.; Canesi, L.; Pertica, M. and Livingstone, D. R. (1991). Seasonal variations in the antioxidant defence systems and lipid peroxidation of the digestive gland of mussels. Comp. Biochem. Phys. C, 100(1-2): 187-190. 
Viarengo, A.; Canesi, L.; Pertica, M.; Poli, G.; Moore, M. N. and Orunesu, M. (1990). Heavy metal effects on lipid peroxidation in the tissues of Mytilus galloprovincialis lam. Comp. Biochem. Phys. C, 97(1): 37-42.

Vinodhini, R. and Narayanan, M. (2008). Bioaccumulation of heavy metals in organs of freshwater fish Cyprinus carpio (Common carp). Int. J. Environ. Sci. Te., 5(2): 179-182.

WHO (1989). Heavy metals environmental aspects. World Health Organization, Environment Health Criteria, (85).

Wiegand, C. and Pflugmacher, S. (2005). Ecotoxicological effects of selected cyanobacterial secondary metabolites: A short review. Toxicol. Appl. Pharm., 203(3): 201-218.

Winston, G. W. and Di Giulio, R. T. (1991). Prooxidant and antioxidant mechanisms in aquatic organisms. Aquat. Toxicol., 19(2): 137-161.

Xu, L.; Zheng, G. J.; Lam, P. K. and Richardson, B. J. (1999). Relationship between tissue concentrations of polycyclic aromatic hydrocarbons and DNA adducts in green-lipped mussels (Perna viridis). Ecotoxicology, 8(2): 73-82.

Zannella, C.; Mosca, F.; Mariani, F.; Franci, G.; Folliero, V.; Galdiero, M. and Galdiero, M. (2017). Microbial diseases of bivalve mollusks: Infections, immunology and antimicrobial defense. Mar. Drugs, 15(6): 182.

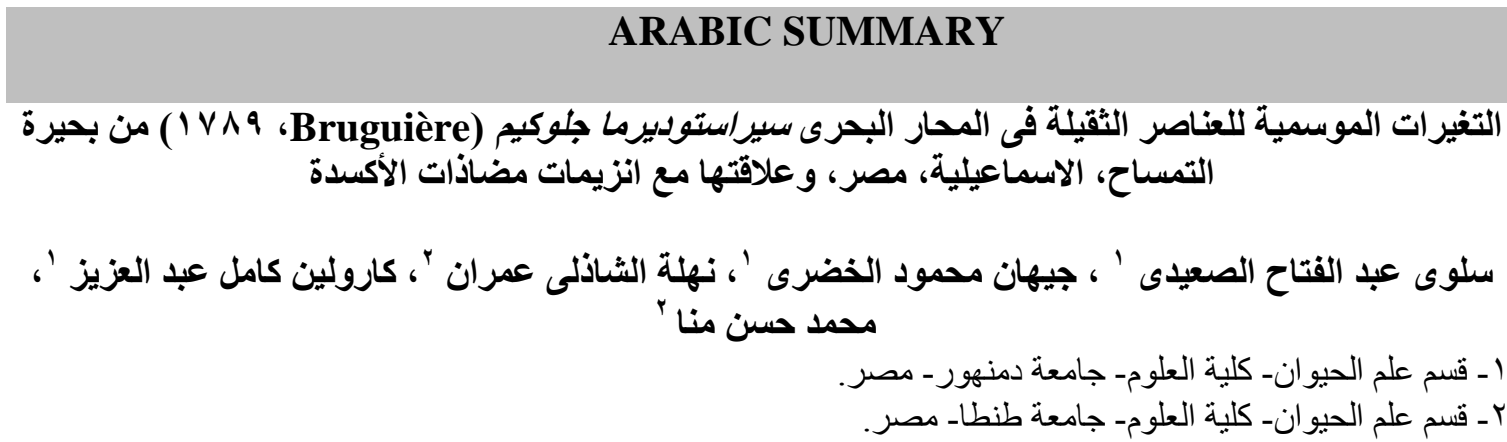

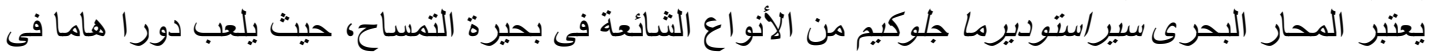

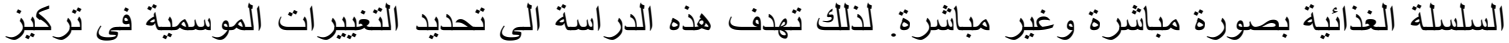

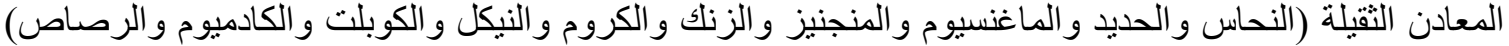

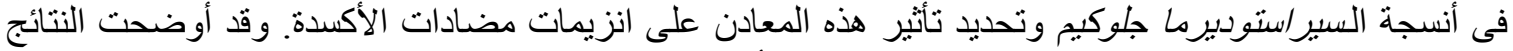

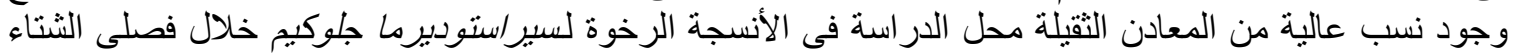

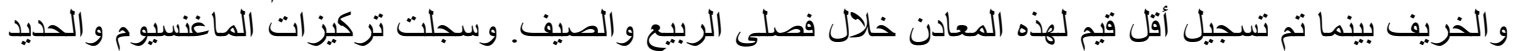

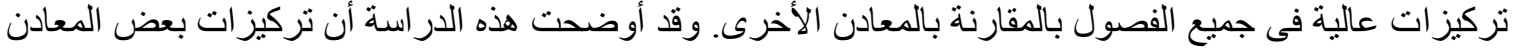

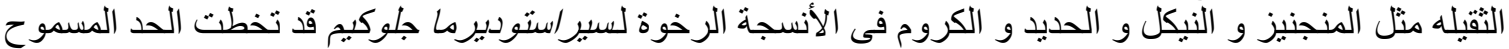

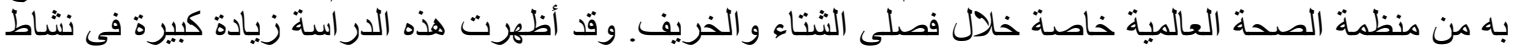

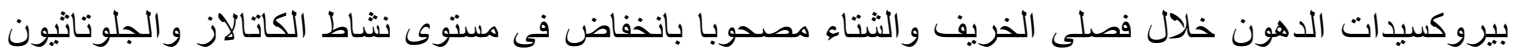

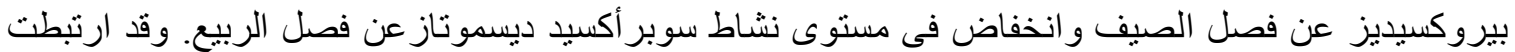

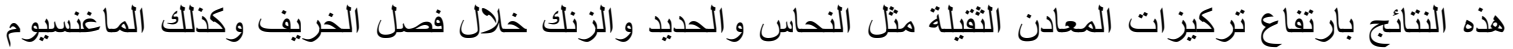

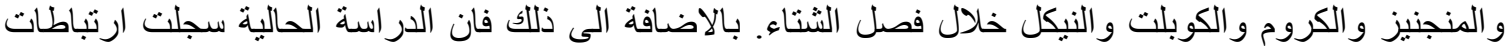

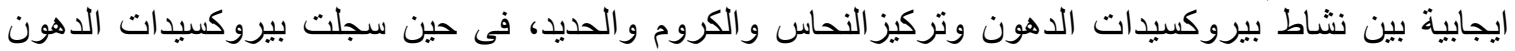

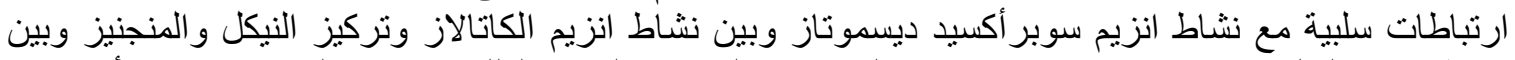

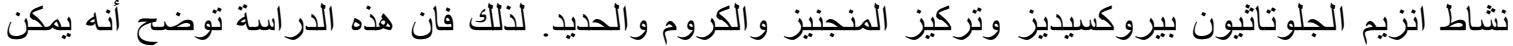

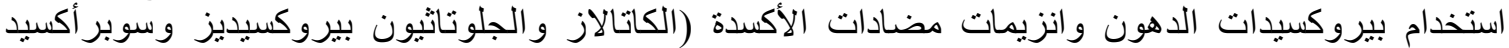

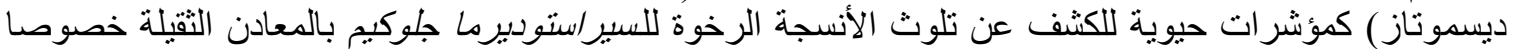

